DOI:10.24193/tras.60E.3

Published First Online: 2020/06/22
IS CULTURAL POLICY

IN POLAND IN THE PROCESS

OF RECENTRALIZATION?

\section{Katarzyna KOPEĆ}

\section{Katarzyna KOPEĆ}

Associate professor, PhD, Institute of Culture,

Faculty of Management and Social Communication, Jagiellonian University, Kraków, Poland

Tel.: 0048-12-664.5818

E-mail: katarzyna.kopec@uj.edu.pl

\section{Abstract}

One of the key mottos of system transformation in Poland after the fall of communism in 1989 was far-reaching decentralization. These transformation processes encompassed also the sector of culture. Now, this strong trend towards decentralization has been mitigated or even reversed. This paper will review many of the concerns which have been articulated in relation to the centralization/decentralization conundrum. The main aim of this paper is to test the assumption that cultural policy in Poland faces recentralization, by means of political, fiscal and administrative indicators to track the dynamics of its recent shifts. To look at this tendency I conducted a comparative analysis of the cultural policy instruments in two periods: the coalition of The Civic Platform and Polish People's Party 20072015, and Law and Justice Party 2015-2017. The study contributes to knowledge of political, fiscal and administrative settings of cultural policy recentralization in Poland.

Keywords: cultural policy, decentralization, recentralization, central and local government, cultural management. 


\section{Introduction}

There is an endless tension between centralization and decentralization in the contemporary states (Sahin, 1973; Cummings, 1995; Vestlund, 2015). Recent decades, in particular the fall of the communism in Eastern Europe at the turn of the 1980s, brought about the tendency towards decentralization which shaped a new facet of governance in transition and in developing countries as well (Bird and Vaillancourt, 1998; Sharma, 2005; Pollit, 2005; Shah and Shah, 2006). Decentralization was seen as a key element of the transition processes (Crook and Manor, 2000) motivated by disenchantment with previous centralized modes of governance (Bardhan and Mookherjee, 2006). There was a popular belief that bringing government closer to the people should result in enhanced efficiency and accountability than its centralized counterpart (Rodríguez-Pose and Ezcurra, 2010; White, 2011; Pina-Sánchez, 2014). The decentralization process, however, was not rarely hampered by fundamental problems including the lack of a clear conception of the role of the state, leftover elements of the previous system that limit the possibility to re-orient budgetary allocations, low vertical coherence reducing reliability and predictability of government actions, weak inter-sectoral co-ordination limiting government abilities to adopt strategic reforms, and mechanical and technical approaches to public administration (Verheijen, Smirl and Kozáková, 2001). Most often, the decentralization agenda has remained incomplete (Prud'homme, 1995; Litvack et al., 1998; Bahl and Martinez-Vasquez, 2006; Kaiser, 2006; Pritchett et al., 2010; Panday, 2017), led to unconstructive implications including the growth of corruption practices (Rose-Ackerman, 2004), or reduced the quality in public service provision (Treisman, 2000).

Decentralization is a multifaceted, complex and ongoing process which has so far produced justifications of both failure and success (Breton, 2002). This process is also highly connected with the understanding of a set of goals central government should strive to achieve. Under certain conditions decentralization might be seen as undesirable since it reduces the control power of the central government over the public sphere (Prud'homme, 1995). Vertical decentralization, measured by the number of sub-national government tiers, also tends to be inefficient (Dreher, 2006). At present, a number of indicators reveal the political tendency towards recentralization motivated by efficiency arguments (Cole and de Visscher, 2016; Loewen, 2018).

Decentralization encompassed a great number of sectors including the cultural sector; cultural decentralization has been extensively researched based on the example of Central and Eastern Europe (Yosifova, 2011; Tóth, 2014; Kristóf, 2017; Kawashima, 2004; Heiskanen, 2001; Inkei, 2009; Berzins, 2005; Katunarić, 2003; Ada et al., 2018). Research indicates that the decentralization process in post-communist countries has often been fragmented and superficial. Furthermore, the recentralization shift occurs in certain countries (Hajnal et al., 2018).

This study was designed to diversify this scholarship by providing an in-depth analysis assessing the condition of recentralization tendency of the cultural sector 
in Poland, but also by bringing a broad political context of decentralization in the cultural policy in Poland. By building on the theory of decentralization this contribution tests the projected reality of cultural policy in Poland. This is important because recentralization contributes to the consolidation of the central government's control power over the public cultural sphere.

The article is structured as follows. First, the literature review section describes the fundamental concepts of decentralization pointing at the heterogeneity of countries' decentralization and tribulations related to the implementation of the decentralization agenda. Second, the paper presents a broader perspective of recentralization process and its implications with a focus on European post-communist countries. The methodology section introduces the research procedure to test the assumption that cultural policy in Poland faces recentralization by means of political, fiscal and administrative indicators to track the dynamics of its recent shifts. Next, the results are presented and discussed, concluding with implications for research and practice.

\section{Decentralization in cultural policy}

Cultural policy is a subsector of public policy (Paquette and Redaelli, 2015). Cultural policy 'is a large, heterogeneous set of individuals and organizations engaged in the creation, production, presentation, distribution and preservation and education about aesthetic heritage, and entertainment activities, products and artifacts' (Wyszomirski, 2002, p. 186). In this article I study explicit cultural policy, i.e. the policy suggestions that the parties themselves refer to as such (Ahearne, 2009).

Decentralization of contemporary cultural policy in Poland began in 1989, when significant system changes were started after 44 years of the socialist economy. In 1990, instead of undemocratic local structures (national councils), democratic communes ('gminy' - the lowest level of local government) with considerably greater powers were introduced. In 1999, the reforms were completed by introducing two additional levels of local government - districts ('powiaty') and provinces ('województwa'). These transformations forced the new local government structures in Poland to formulate and implement cultural policy in a new reality that would take into account regional and local needs (Murzyn-Kupisz, 2010).

However, the system of cultural policy management decentralized after 1989 has still remained centralized in its nature. The reason for 'more formal than substantial' decentralization lies (at least partly) in the way administrative reforms shifted the responsibility for culture to regional and local governments (without adequate redistribution of financial resources). Low level of financial autonomy of cultural institutions resulted in their administrative dependency and politization that made it easier for those institutions to function (Głowacki et al., 2009).

Being aware that decentralization 'is an ambiguous concept, its borders not well defined' (Prud'homme, 1995, p. 2), when assessing each model of decentralization, questions appear about the effectiveness of the developed level of the decentralization of the cultural policy, that is raising questions about the rationality of the decisions 
taken in a given model, about the optimal proportions between what should be the center, and what lower-level authorities should deal with.

Decentralization in cultural policy is one of the most frequently mentioned goals of conducting cultural policy in many countries (Cummings and Katz, 1987, p. 367), including post-communist countries of Central and East Europe and Southeastern Europe (Weeda et al., 2005; Tóth, 2011; Tóth, 2014; Katunarić, 2003; Inkei, 2009). Decentralization gains specific weight in these transition countries which still carry the legacy of a centralized system (Alagjozovski, 2004). Despite the uniqueness of each of these countries they share comparable historical context of communism which strongly affects the shape of cultural policy. The post-transition era has shown that political and state systems in countries of this region generally lack solid and effective guarantees for the representation of territorial interests, and the EU key idea of subsidiarity is underrepresented. It makes the implementation of decentralization fulfill only partially. In Bulgaria, the process of decentralization of cultural policy is seen as a fusion of inconsistent political decentralization and consistent shift of the financial responsibility from the state to the municipal budgets (Yosifova, 2011). In Romania, the first wave of decentralization was made under the society pressure, and was unsuccessful because neither the way of thinking was changed, nor the institutions were ready for this step (Chetraru, undated). In many transition countries of this region the speed of introducing decentralization moved too fast (Kovács et al., 2016). However, despite a strong drive to decentralize, the capacity for autonomous regional initiatives has been reduced (Suteu, 2012). Frequently, there was no clear strategy to understand and develop cultural policy (Bulgaria, Macedonia) (Alagjozovski, 2004). In consequence, to different extent in every country, a new recentralization of the system was put in practice and cultural institutions entered once again under the central authority subordination (Chetraru, undated).

In literature, economic and political effects of decentralization or more specifically recentralization of cultural policies on the performance of this sector can be distinguished; however, the benefits of decentralization are not obvious (Prud'homme, 1995; Kovács et al., 2016). There are studies finding out both negative and positive correlation with traditionally assumed positive impacts of decentralization (Sharma, 2006). However, decentralization has been developed into the most favored policy priority which has been implemented very differently in different countries.

In general, the key objective of cultural decentralization is spatial diffusion of arts-related facilities and organizations to benefit audience and population at large (Kawashima, 2004). From the economic point of view, decentralization of cultural policy strives to equalize public expenditure regionally for the arts and culture (Kawashima, 2004). Decentralization makes it possible to distribute public funds efficiently by different spending authorities among different groups of cultural producers (Kawashima, 2004). From the political point of view decentralization allows to diffuse political and administrative power to implement cultural policy by different decision-makers, including horizontal diffusion of responsibilities among different stakeholders of pub- 
lic, private and non-profit sector (Kawashima, 2004). Prud'homme (1995) underlines possible negative effects (both economic and political) of decentralization including increasing disparities and corruption, harming stability, and undermining efficiency. Frequently, a real challenge of successful decentralization is what functions to decentralize, in which sectors, in which regions and how to harmonize shared production of the service by the various levels (Prud'homme, 1995).

Kawashima (2004) defines cultural decentralization as a fair distribution of cultural products among citizens by creating equal opportunities in the consumption of culture for every citizen irrespective of his/her gender, race, beliefs or income. The following types of decentralization of cultural policy can be distinguished (Flejterski and Zioło, 2008; Kawashima, 2004):

- political (system) decentralization assumes that lower-level entities operate through democratically elected executive and decision-making bodies. The highest degree of system decentralization is expressed in the system independence of the local government from the central government.

- fiscal decentralization (decentralization of public finance), which concerns the distribution of public expenditure on culture, with the proportions between expenditure from the central and local government level that ensure balancing the level of public expenditure on culture in the region. This refers particularly to the transfer of public financial resources from the central government level to local governments in order to guarantee financing the tasks carried out by local governments and financial independence of the local governments.

- administrative decentralization, which consists in defining the scope of tasks of local governments of particular levels and equipping these entities with administrative tools enabling the implementation of the tasks entrusted to them. Administrative decentralization can be divided into: de-concentration (the lowest level of decentralization), delegation and devolution (the highest level of decentralization).

\section{Method and data}

The primary aim of this research is to test the assumption that cultural policy in Poland faces recentralization by means of political, fiscal and administrative indicators, and to track the dynamics of its recent shifts. There is an important underlying reflection that Polish cultural policy is an area in which decentralization has been rather formally than substantially developed. The following research procedures are used in the article: (1) integrative literature review which looks at decentralization in the cultural policy with a special focus on European post-communist countries, (2) historical approach which shows steps made towards decentralization and critical insights on its implementation, and (3) policy discourse analysis which deals with the assessment of political, fiscal and administrative settings of cultural policy decentralization/recentralization. The policy discourse analysis is based on the theoretical framework developed by Ebel and Yilmaz (2002) to measure correlation between fiscal 
decentralization and economic growth. Out of three groups of indicators, three specific indicators relating to cultural policy have been specified - one for each group.

- For the indicator of political decentralization - the scope of central government participation in the decision-making process, including state interventionism, which is reflected in influencing the repertoire, as well as content and values in cultural activities. As this indicator is not subject to quantitative analysis, it will be discussed on the basis of declarations included in the programs of winning political parties in this period: Civic Platform in 2007 ('Poland Deserves the Economic Miracle') and 2011 ('The Next Step. Together'), and Law and Justice in 2014 ('Health, Labor, Family'). It consolidates and describes the approach towards decentralized cultural policy implementation. Election programs are temporal and declarative. They do not necessarily correspond with real undertakings; however, they do attempt at imposing selected politically driven narratives to be implemented after winning elections.

- For the indicator of decentralization of public finances - the ratio of expenditures of local government units and total public expenditure on culture. This indicator based to a greater extent on quantitative data shows how political declarations translate into real actions in cultural policy.

- For the indicator of administrative decentralization - the structure of the public cultural sector from the point of view of the subordination of cultural institutions - whether the managing unit of a cultural institution is a central body or local government. This indicator prioritizes strategic moves outlined in the cultural policy.

The analysis looking at the decentralization/recentralization issue is not (or not especially) susceptible to quantitative research' (Manor, 2011, p. 1). Researchers (Ebel and Yilmaz, 2002) emphasize a great difficulty in measuring the degree of decentralization based on the example of only one indicator of fiscal decentralization. The idea to measure the degree of decentralization has been largely inconclusive mainly due to no consensus among scholars on its precise definition (Sharma, 2006). Many papers address this issue in economics, but no attempts have been made to measure the degree of cultural decentralization. A number of studies have developed qualitative research aiming at assessing the quality and the way decentralization in the cultural sector functions. Thus, the aim of this paper is not to rigorously measure the degree of advancement of decentralization/recentralization, but to verify that cultural policy has been recentralized since 2015 . Therefore, it contributes to the debate largely by providing knowledge on the complex process of decentralization in the cultural policy in Poland and its present condition. Below the analysis mostly relies on qualitative study and to some extent on quantitative evidence to look more precisely at some tendencies.

Two periods will be analyzed, taking into account three indicators: political, fiscal and administrative decentralization. The first period covers the years 2007-2015 - the 
period of the coalition of the Civic Platform (PO) and the Polish People's Party (PSL). The first coalition government was formed after the parliamentary elections of October 21,2007 . The second PO-PSL coalition government was formulated after the subsequent elections in 2011 and lasted until September 2014. The PO-PSL governments were a continuation of the transformations initiated in 1989 and fitted into the political model called the Third Republic of Poland.

The second period covers the years 2015-2017. It began when the Law and Justice Party (PiS) came to power and formed a one-party government (it has been functioning until now - as of the end of 2019) - however, only the initial period was taken into account due to the availability of statistical data). The comparability of the analysis of these two periods - the PO-PSL coalition government and the PiS government - is hindered by disproportionate time frames of these two periods, and the difficulty in interpreting trends from 2015, which was a transitional period (the PiS government came to power on November 16, 2015). However, it was recognized that even such a short period (the data concerning the PiS government cover only two full years - 2016 and 2017) may reveal interesting trends. The obvious premise that the PiS government may constitute an interesting point of reference, or even a counterpoint to the governments of the PO-PSL coalition, is the fact that the continuity of the political system was to some extent broken with the negative evaluation of the entire legacy of 1989 by PiS politicians.

\section{The decentralization of cultural policy in Poland. Findings}

\subsection{Political (system) decentralization}

The Civic Platform's programs from 2007 and 2011 both call for deetatization and strengthening the autonomy of self-governments. From the political point of view the Civic Platform's programs show the decentralization of cultural policy. In both programs culture was perceived as a carrier of pluralism, individuality and dialogue, but also as an element of economic development. This made a clear link between trends in European cultural policies (Bieczyk-Missala, 2016), and the call to create favorable conditions for the development of the culture industry and strengthening civil society. According to the programs' vision, the responsibility for decentralized cultural sector was spread among the state, local governments and non-governmental organizations. This kind of horizontal cooperation was visible in extensive grant programs designed to support diverse cultural NGOs. Partially adapted Anglo-Saxon solutions (e.g. arm's length principle, state lotteries) were highly attractive for the Polish model, which was to be a step to strengthen the autonomy of the entities engaged in cultural activities and diminish the influence of the state on cultural institutions (a step towards the decentralization of the sector). The call for diversification of funding sources showed again the Anglo-Saxon way of thinking (e.g. the call for sponsorship) to be implemented in a country where philanthropy just started to revive after a long break.

The Law and Justice election program displays the characteristics of recentralization trends in this area. Its current implications are visible on various levels, and from 
the point of view of cultural policy they negatively affect the Polish cultural system (Kubecka, 2015). The Law and Justice cultural policy is ideologically marked and realizes the vision of culture subordinated to the state. There is a very strong accent put on the role of the state in the sphere of culture (the state as a caretaker and guardian of culture). It clearly focuses on several areas: history and identity policy, supporting Polish heritage and traditions, participation of broad social groups in culture (Kubecka, 2015), promoting Christian and patriotic values. This stays in contrast with the Civic Platform's vision that understood culture as a laboratory of the future, changeability, and pluralism.

The Law and Justice party shows its clear preference to directly manage cultural sphere to instrumentally reach its centralist goals. Its cultural policy forces the implementation of centralized mechanisms giving the authorities the mandate to have a hold over nearly all the cultural sector by means of diverse instruments (including financial or personal) to make the message consistent with the values articulated by the central authority. Again, as a result, there are ineffective organizational structures and financing based mainly on public subsidies to those organizations that implement the ideological vision of the Law and Justice party. Thus, cultural institutions might be treated instrumentally, losing their autonomy in the field of running cultural programs. This recentralization trend is visible also in the excessive concentration of the public sector on the protection of cultural heritage instead of promoting new cultural values, while initiatives promoting other, liberal values are not supported.

\subsection{Fiscal decentralization (public finance) decentralization}

Public funding is one of the main sources of financing culture in Poland, both for public and non-governmental organizations, where public subsidies compose $55 \%$ of their income (Adamiak et al., 2016). Cultural institutions organized by local governments constitute the dominant group in the landscape of cultural institutions in Poland, which also explains the prevalence of local government expenditure on culture in total amounts spent on culture.

In the years 2007-2014, expenditure in the state budget chapter 921 'Culture and protection of national heritage' was small in relation to expenditure in other chapters, and constituted on average $0.5 \%$ of the state budget expenditure. In 2015, there was a clear increase in the expenditure on culture in the total state expenditure to $0.62 \%$, and it reached $0.89 \%$ in 2017. Cumulatively from 2007 to 2017, a total of PLN 20,288 million was spent on culture from the state budget (an average of PLN 1,844.4 million a year). Culture expenditure grew from PLN 1,313.7 million in 2007, 1,964.8 million in 2015 to PLN 2,586.7 million in 2016 and 3,331.9 in 2017 - in 2016 when the Law and Justice party was in power, a significant increase in expenditure from the state budget on culture was recorded by $31 \%$ in relation to the previous year (see Figure 1).

The share of expenditure in particular budget chapters changed during the analyzed period, however, some general trends are visible. Expenditure in the budget chapter Museums increased (from 23.9\% in 2007 to 28.8\% in 2015). In 2016 expenditure 


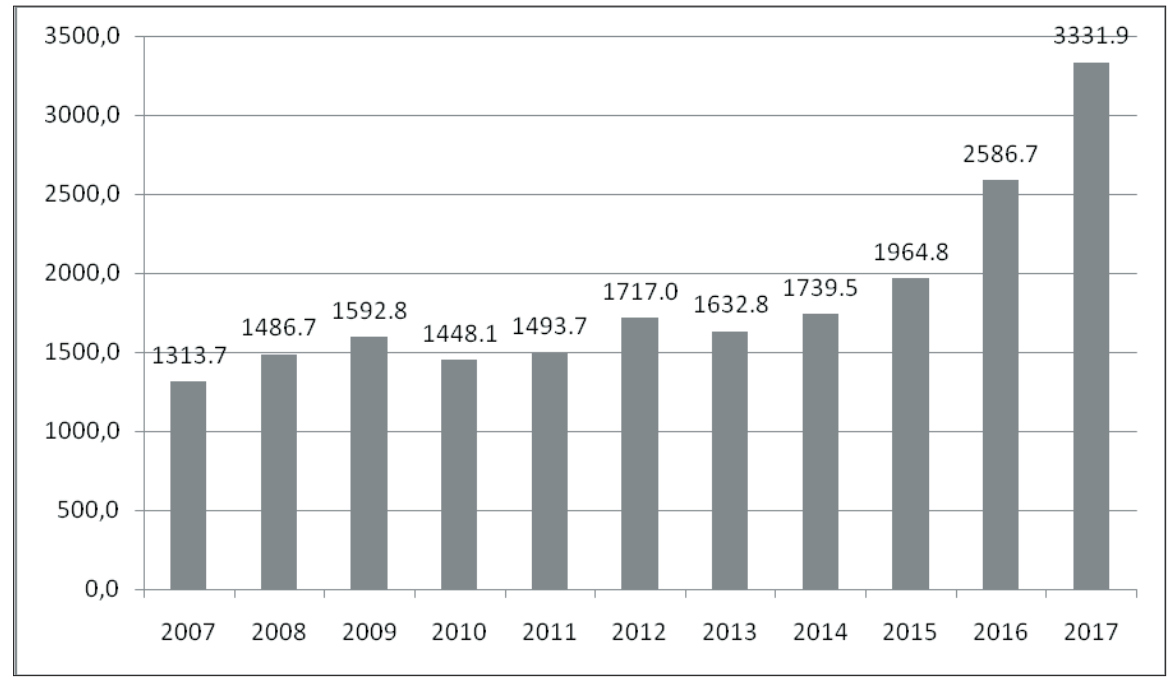

Figure 1: State budget expenditure on culture and protection of national heritage 2007-2017 (MIn PLN)

Source: Główny Urząd Statystyczny (Statistics Poland), Culture in 2007, 2008, 2009, 2010, 2011, 2012, 2013, 2014, 2015, 2016, 2017

on museums increased significantly to $45.1 \%$ (the largest share of the state budget for culture), what nominally was the amount of 1,132,984 thousand PLN. These statistics clearly indicate that museums are the priority in financing culture in Poland. For example, the funds were used to purchase a unique Czartoryski Family Art Collection (476.614,8 thousand PLN) (Najwyższa Izba Kontroli, 2018, p. 14), and to finance at least several multiannual initiatives in line with history policy pursued by the Law and Justice government at the end of 2015 and in 2016.

A particular attention must be given to the figures in 2017. In 2017, museums were still an important chapter covered by the state budget, however, at that time it was the second largest expenditure (reduced level of financing to $19.1 \%$ of the state expenditure on culture from the chapter 921, that is, in 2017 museums received subsidies in the amount of 559.346 thousand PLN whereas in 2016 it was 1.132.984 thousand PLN) (Report on the National Public Budget Execution).

The largest expenditure in 2017 was exceptionally planned in the budget chapter TV and radio broadcasting - 980,000 thousand PLN (that is, 30.1\% of the state expenditure in the state budget chapter 921). This resulted from the change of the Budget Act. The argument for such a significant expenditure was to recompensate public TV and radio the decrease in income from the broadcast receiving license in Poland in the period 2010-2017 (Report on the National Public Budget Execution). In the Polish reality it is a signal of political significance to support a state-financed media that are seen as a government propaganda tool (Klepka, 2017).

The participation of the local and regional governments in financing culture oscillated around 80\% between 2007 and 2010, with a slight upward trend (although it was 


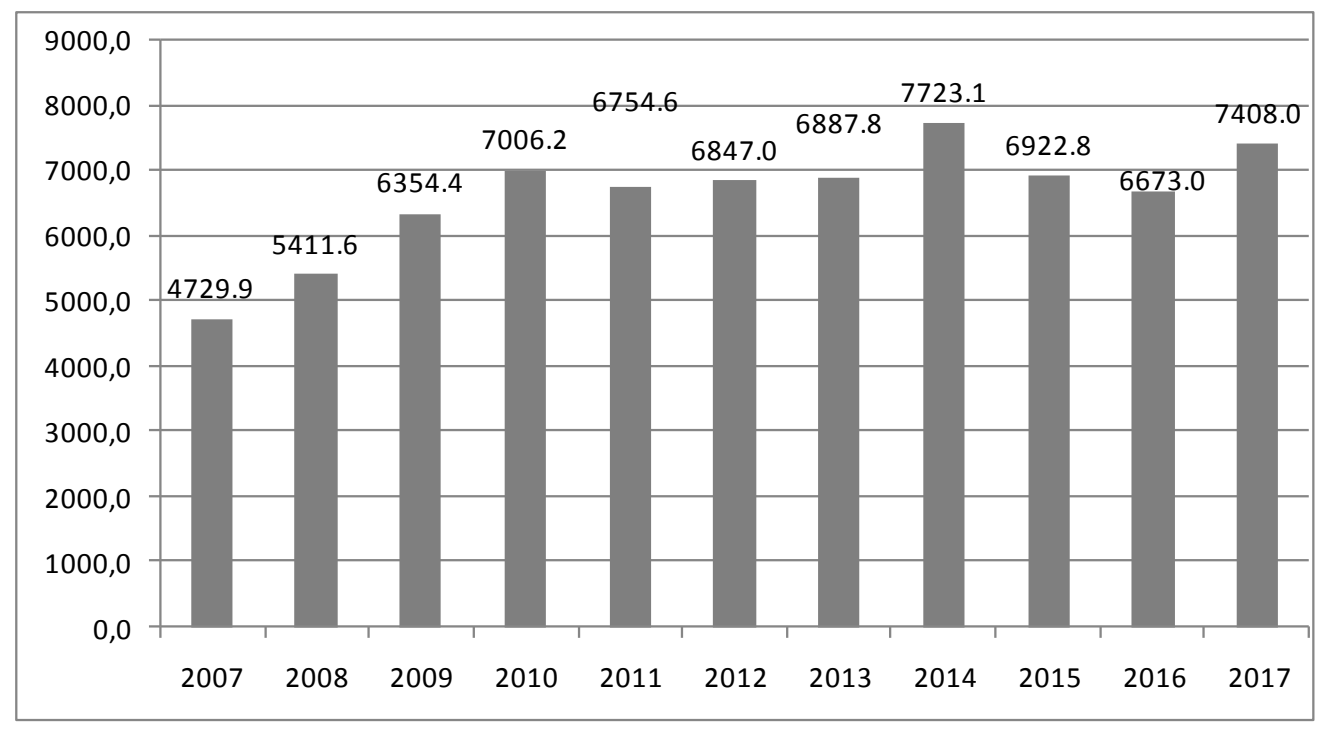

Figure 2: Expenditure of local governments on culture and protection of national heritage 2007-2017 (MIn PLN)

Source: Główny Urząd Statystyczny (Statistics Poland), Culture in 2007, 2008, 2009, 2010, 2011, 2012, 2013, 2014, 2015, 2016, 2017

not a permanent trend). It was a sign of a gradual - though evolutionary - moving the accent in funding culture on the level of self-governments (see Figure 2). In 2014, the last full year of Civic Platform government, it was $81.4 \%$. This trend was rapidly reversed at the time the Law and Justice party came into power.

During the next years, and especially in 2017, there was a sharp decline in the share of local governments in financing culture, to $69.4 \%$. Simultaneously, there was a significant increase in the share of central budget expenditure. In the area of financing, the centralization trend is clearly visible (see Figure 3).

The implications of the tendency for growing expenditure on culture from the state budget include e.g. acquisition and creation of new cultural state institution of ideological profile in 2015-2016, and a huge subsidy in the budget chapter TV and radio broadcasting in 2017. This results from a political decision to establish and finance new national institutions which are subordinated to the center, also ideologically. In consequence, there is an apparent shift towards more extensive central funding of culture with an accent put on those initiatives which promote values important for the state.

The belief of Law and Justice cultural statements is that it is required for state funded culture to meet standards set up by the government. The effect is to limit the autonomy of the cultural sector. Decentralization might be seen as undesirable since it reduces the control power of the central government over the public cultural sphere. This situation is assessed negatively (Musiałek et al., 2019), and its selected features remind of previous communistic autocratic system (lesser transparency of 


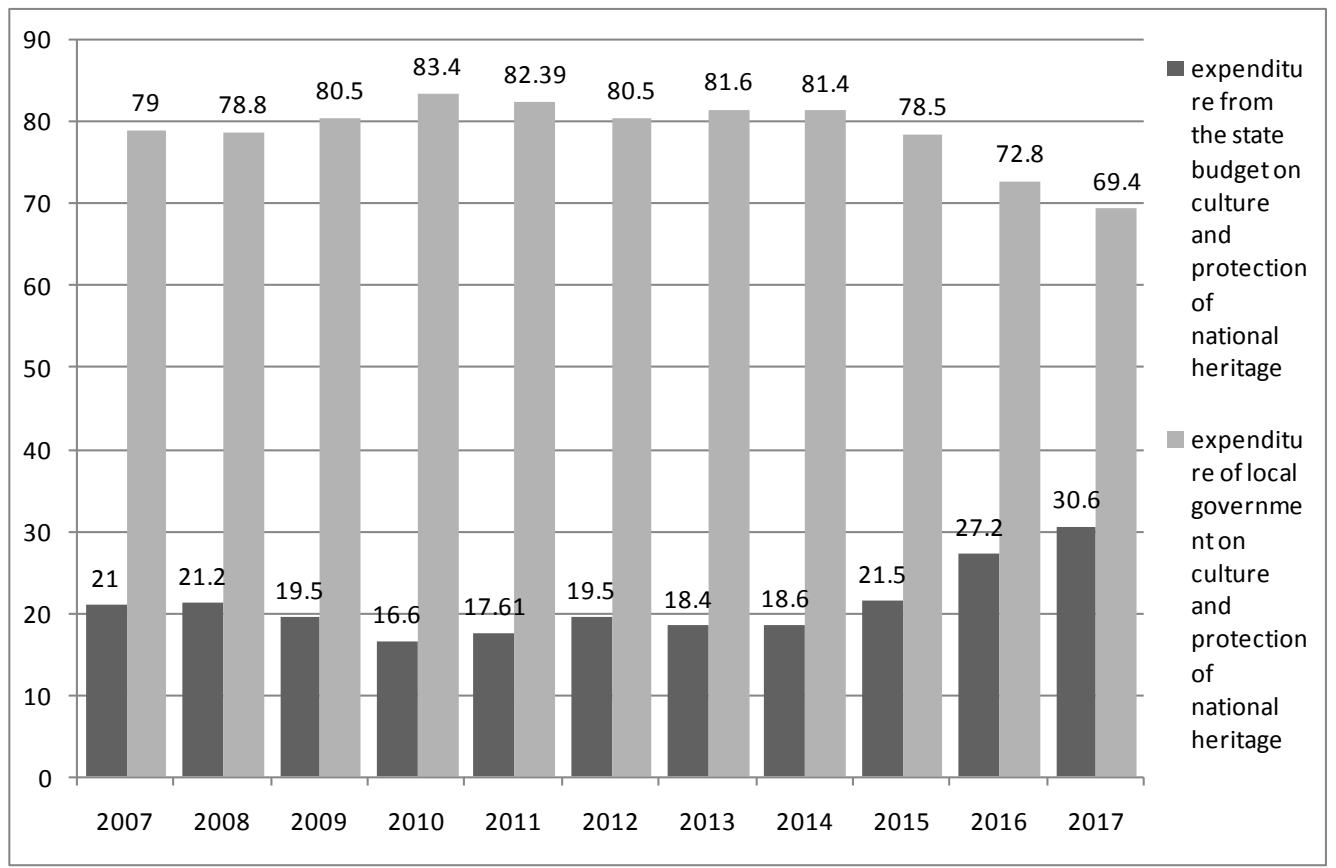

Figure 3: Structure of public expenditure on culture and protection of national heritage 2007-2017

Source: Główny Urząd Statystyczny (Statistics Poland), Culture in 2007, 2008, 2009, 2010, 2011, 2012, 2013, 2014, 2015, 2016, 2017

public funds spending, excessive dependence of cultural entities on public financing, financial subsidies given by public governance levels to public cultural institutions or NGOs following an ideological path of the Law and Justice, strengthening the controlling power of the Ministry of Culture and National Heritage).

\subsection{Administrative decentralization}

The Ministry of Culture and National Heritage finances or co-finances the activities of many organizational units subordinated to and supervised by the ministry, including approx. 300 budgetary units - holders of state budget funds, and about 100 organizational units subordinated to and supervised by the minister.

The Civil Platform - Polish People Party coalition brought minor changes to the number of state cultural institutions. Very few new institutions were established at the time. Overall, 41 state institutions were run in 2007, while this number increased to 48 in 2014 (Report on the National Public Budget Execution, 2007, 2014, 2015, 2016). This period was of evolutionary type in terms of establishing new state cultural institutions - changes in this area were small. There is some regularity in spatial distribution - some regions have invariably the highest number of cultural entities or they have certain types of cultural entities. Some entities, due to the nature of their activities, usually operate in certain areas - theatres, music institutions (e.g. philharmonic 
orchestras), and multiplex cinemas are most often located in large cities, while in small towns and villages there are cultural or community centers. The very important benefit of decentralization, that is, territorial diffusion of cultural establishments and broad access of citizens to cultural facilities has been unchanged despite recentralization trends.

However, the short period under the Law and Justice government shows interesting recentralistic trends in running cultural policy. In 2016, there was an increase in the number of state cultural institutions (6 institutions were established) and in the number of cultural institutions run together with local governments ( 3 institutions more). This trend continues after 2016, with a further growth of the state entities. In 2017, 9 state cultural institutions were established out of them 5 were new institutions and 4 were established as result of the merge of cultural institutions whose programs profiles were comparable. Also, in 20178 cultural institutions started to be run together with local governments, while in 20182 new institutions were established (Registers of cultural foundations and institutions).

The government of the Law and Justice revealed the trend to establish new cultural institutions that are managed centrally and which are clearly aimed to promote values preferred by the party. It shows the inclination towards selective and centralized cultural policy. Among newly established state institutions or institutions transformed recently into state institutions are: Museum of Polish History in Warszawa, Józef Piłsudski Museum in Sulejówek, National Institute of Polish Cultural Heritage Abroad, National Institute of Architecture and Urban Planning, and Polish Royal Opera. Administrative recentralization is employed here as an instrument to formulate clear, symbolic message approved from the top that concentrates on history and identity policy, and promotes Polish heritage and tradition.

Subordination plays here the crucial role. Since the Law and Justice government, the center increasingly has participated in the cultural administration playing the role of the sole decisive body in the cultural policy. Its direct implication is that the center takes decisions that the periphery simply executes; it is clearly seen in the profile of all cultural institutions established by the Law and Justice Party, promoting history policy, patriotism and Christian values, and omitting references to European conditions and experiences; an example is the controversy related to administration of the Museum of the Second World War (Paszulka, 2019). This profile explains the nature of expenditure (a clear increase in state budget expenditure on museums, i.e. institutions implementing the above-mentioned postulates of the ruling party).

The next important implication of administrative recentralization is the pressure to politically appoint or replace previous directors of cultural institutions (e.g. in May 2019 Dariusz Stola won the competition for director of POLIN Museum of the History of Polish Jews, but the Minister of Culture politically has not accepted the selected candidate and has not appointed him to the post) (Dariusz Stola's Statement). Also, there are a lot of examples of replacing directors of cultural institutions with managers agreeing with the Law and Justice's vision of cultural policy (Chaciński, 2019). 
Again, from the point of view of cultural policy, those examples negatively affect the performance of cultural organizations that should meet diverse expectations of citizens and other stakeholders of cultural policy (Chaciński, 2019). At this recentralization trend, administrative power allows to diffuse political and administrative power to implement cultural policy by different decision-makers, as long as different stakeholders pursue the ideological profile of the cultural policy set by Law and Justice.

\section{Conclusions}

Not much research on recentralization trends in cultural policy of CEE countries has been conducted. This study contributes to recent academic debates, reinforcing the view that decentralization of cultural sector in CEE countries was only partly successful, and brought a wave towards recentralization. Cultural policy analysts can be informed through this study about the conditions of running cultural policy in Poland. This might enhance understanding of practical matters as far as cultural policy is concerned.

This research allows to point at re-centralization wave in Poland since the Law and Justice Party came into power (2015). Poland is not the only country incorporating this tendency. In Hungary, Fidesz, a national-conservative and right-wing populist political party brought about fundamental changes also in cultural policies, that is, decision-making by high level functionaries (Inkei, 2016) and the discourse of patriotism-nationalism (Kristóf, 2017, p. 19).

In the Polish cultural policy, the trend toward decentralization in the 1990s (but it was the so called centralized decentralization) and presently towards recentralization has blurred the clear distinction between the responsibilities of different actors and their functions (profiling cultural service provision, its financing, and supervising). It might result from leftover elements of the previous system, which negatively affect horizontal and vertical coherence of the government actions and intersectoral cooperation.

The possible implications of current recentralization trend might be seen as 'instrumental cultural policy' (Gray, 2007) that refers not to use cultural resources to implement purely cultural or artistic objectives but to an emphasis on secondary purposes such as developing right-wing narratives about the Polish identity and national pride or support other political purposes by means of various instruments. Current recentralization wave unveils not only increasing participation of the center in financing culture (fiscal factor), but also retaining the central power to appoint representatives of regional authorities and influencing the decisions of regional bodies (administrative factor), as well as insisting on supporting a selected range of cultural projects to be implemented - the party opposes public funding of culture that is not perceived as part of the national (political factor). Recentralization contributes to the consolidation of the central government's control power over the public cultural sphere.

This conclusion emphasizes the need to explore the capacity, implementation and policy constraints of this process. What is the quality of cultural services provided 
in the centralized and decentralized system? Do central government and also local governments have a long-term concept of what organization is going to provide, what kind of cultural services and to what extent? If a stronger role of the center has emerged in the consequence of recentralization, what role will non-governmental organizations and private sector organizations play in cultural policy? What are possible joint elements of recentralization process in CEE countries?

\section{References:}

1. Ada, S., Dragicevic-Šešic, M. and Vickery, J. (eds.), Cultural Policy and Populism. Cultural Policy Yearbook 2017-2018, Istanbul: Iletism Publishing 2018.

2. Adamiak, P., Charycka, B. and Gumkowska, M., 'Kondycja Sektora Organizacji Pozarządowych w Polsce 2015. Raport z Badań' (NGOs in Poland 2015. Research Report), Warszawa, 2016.

3. Ahearne, J., 'Cultural Policy Explicit and Implicit: A Distinction and Some Uses', 2009, International fournal of Cultural Policy, vol. 15, no. 2, pp. 141-153.

4. Alagjozovski, R., 'Cultural Decentralization in Macedonia: Chance or Threat?', July 2004, [Online] available at https://www.eurozine.com/cultural-decentralization-in-macedonia-chance-or-threat/, accessed on November 20, 2019.

5. Bahl, R. and Martinez-Vasquez, J., 'Sequencing Fiscal Decentralization', Policy Research Working Paper 3914, Washington, D.C.: World Bank, 2006.

6. Bardhan, P. and Mookherjee, D., 'Decentralization, Corruption and Government Accountability', in Rose-Ackerman, S. (ed.), International Handbook on the Economics of Corruption, Cheltenham: Edward Elgar Publishing, 2006, pp. 161-188.

7. Berzins, I., 'Privatisierung im Kulturbereich. Lettland auf dem Wege vom Staatsapparat zur Freien Kulturlandschaft' (Privatization in the Cultural Field. Latvia on the Way from the State Apparatus to a Free Cultural Landscape), 2005, Ph.D. Thesis, University of Münster, Germany.

8. Bieczyk-Missala, A., 'Poland's Foreign and Security Policy: Main Directions', 2016, Revista UNISCI, vol. 40, pp. 101-117.

9. Bird, R.M. and Vaillancourt, F. (eds.), Fiscal Decentralization in Developing Countries, Cambridge: Cambridge University Press, 1998.

10. Breton, A., 'An Introduction to Decentralization Failure', in Ahmad, E. and Tanzi, V. (eds.) Managing Fiscal Decentralization, London: Routledge, 2002, pp. 31-45.

11. Central Statistical Office, Statistical Office in Krakow, 'Finanse Kultury w Latach 20072015' (Finances in the Cultural Field 2007-2015), GUS, Kraków, 2016.

12. Chaciński, B., 'Cztery Lata Rządów PIS: w Kulturze Najbardziej Udała Się Sztuka... Dzielenia' (Four Years of PIS Rule: Art Has Succeeded in Culture ... Sharing), Polityka, September 12, 2019, [Online] available at https://www.polityka.pl/tygodnikpolityka/kultura/1924208,1,cztery-lata-rzadow-pis-w-kulturze-najlepiej-sie-udala-sztuka-dzielenia.read, accessed on February 25, 2020.

13. Chetraru, V., 'Evolutions of the Cultural Policy. Romania from 1989 to 2006', undated, [Online] available at http://culturaldiplomacy.org/academy/content/articles/events/2011loam/ participant-papers/Evolutions_of_the_Cultural_Policy_Romania_from_1989_-_2006.pdf, accessed on November 20, 2019. 
14. Cole, A. and de Visscher, C., 'Les Régions Belges Face à la Crise Économique: Une Recentralisation à Distance pour la Wallonie?', 2016, Revue of Internationale de Politique Comparée, vol. 23, no. 3, pp. 301-325.

15. Crook, R. and Manor, J., 'Democratic Decentralization', OECD Working Paper Series no. 11, Washington, D.C.: World Bank, 2000, [Online] available at http://ieg.worldbankgroup. org/sites/default/files/Data/reports/demcratc.pdf, accessed on November 20, 2019.

16. Cummings, M.C. and Katz, R.S., 'Government and the Arts in the Modern World: Trends and Prospects', in Cummings, M.C. and Katz, R.S. (eds.), The Patron State: Government and the Arts in Europe, North America, and Japan, Oxford: Oxford University Press, 1987, pp. 350-368.

17. Cummings, S., 'Centralization and Decentralization: The Never-ending Story of Separation and Betrayal', 1995, Scandinavian fournal of Management, vol. 11, no. 2, pp. 103-177.

18. Dreher, A., 'Power to the People? The Impact of Decentralization in Governance', KOF Working Paper no. 121, Zürich: Swiss Institute for Business Cycle Research, 2006.

19. Ebel, R. and Yilmaz, S., 'On the Measurement and Impact of Fiscal Decentralization', Policy Research Working Paper no. 2809, Washington, D.C.: The World Bank, 2002, [Online] available at https://openknowledge.worldbank.org/bitstream/handle/10986/14821/multi 0page.pdf?sequence=1\&isAllowed=y, accessed on November 20, 2019.

20. Flejterski, S. and Zioło, M., 'Centralizacja i Decentralizacja Zadań Publicznych w Świetle Wybranych Rozwiązań Europejskich. Próba Oceny’ (Centralization and Decentralization of Public Tasks in the Light of Selected European Solutions. Evaluation), 2008, Studia Regionalne i Lokalne, vol. 33, no 3, pp. 76-94.

21. Głowacki, J., Hausner, J., Jakóbik, K., Markiel, K., Mituś, A. and Zabiński, M., 'Finansowanie Kultury i Zarządzanie Instytucjami Kultury' (Financing Culture and Managing Cultural Institutions), Kraków, 2009, [Online] available at http://www.kongreskultury.pl/library/ File/RoSK\%20finansowanie/finansowanie_w.pelna.pdf, accessed on June 16, 2020.

22. Główny Urząd Statystyczny (Statistics Poland), 'Kultura w 2007, 2008, 2009, 2010, 2011, 2012, 2013, 2014, 2015, 2016, 2017' (Culture in 2007, 2008, 2009, 2010, 2011, 2012, 2013, 2014, 2015, 2016, 2017), Warszawa, [Online] available at https://stat.gov.pl/obszary-tematyczne/ kultura-turystyka-sport/kultura/kultura-w-2007-r-,2,5.html, accessed on June 16, 2020.

23. Gray, C., 'Instrumental Cultural Policies: Causes, Consequences and Museums', paper presented at Arts and Humanities Research Council Instrumental Museum and Gallery Policy Conference, University of Glasgow, October 2007.

24. Hajnal, G., Kadar, K. and Kovacs, E., 'Public Administration Characteristics and Performance in EU28: Hungary', in Thijs, N. and Hammerschmid, G., The Public Administration in the EU28, Luxembourg: Publication Office of the European Union, 2018, pp. 424-459.

25. Hausner, J., Karwińska, A. and Purchla, J. (eds.), Kultura a Rozwój (Culture and Development), Warszawa: National Cultural Centre, 2013.

26. Heiskanen, I., 'Decentralisation: Trends in European Cultural Policies', Cultural Policies Research and Development Unit, Policy Note no. 9, Strasbourg: Council of Europe Publishing, 2001.

27. Inkei, P., 'Culture and Development 20 Years after the Fall of Communism in Europe', paper presented at The Culture Watch Europe Conference, June 4-6, 2009, Kraków, Poland.

28. Kaiser, K., 'Decentralization Reforms', in Coudouel, A. and Paternostro, S. (eds.), Analyzing the Distributional Impacts of Reforms, Washington, D.C.: World Bank, 2006, pp. 313-353. 
29. Katunarić, V., 'Decentralisation in South East Europe: Objectives, Instruments, Practices', 2003, [Online] available at http://www.policiesforculture.org/dld/PfC_VKatunaric_SEEDecentralisation.pdf, accessed on June 15, 2019.

30. Kawashima, N., 'Planning for Equality? Decentralisation in Cultural Policy', Research Papers No. 1, Center for Cultural Policy Studies, University of Warwick, 2004, [Online] available at http://wrap.warwick.ac.uk/37189/1/WRAP_Kawashima_ccps_paper_1.pdf, accessed on June 16, 2019.

31. Klepka, R., 'Ewolucja Wiadomości TVP1: Od Medialnej Stronniczości do Propagandy Politycznej' (TVP1 News Evolution: From Media Bias to Political Propaganda), in Batorowska, H., Walka Informacyjna. Uwarunkowania - Incydenty - Wyzwania, Kraków: Pedagogical University Press, 2017, pp. 244-253.

32. Kovács, I.P., Bodor, Á., Finta, I., Grünhut, Z., Kacziba, P. and Zongor, G., 'Farewell to Decentralisation: The Hungarian Story and Its General Implications', 2016, Croatian and Comparative Public Administration, vol. 16, no. 4, pp. 789-816.

33. Kristóf, L, 'Cultural Policy in an Illiberal State. The Case Study of Hungary after 2010', 2017, Intersections. East European fournal of Society and Politics, vol. 3, no. 3, pp. 126-147.

34. Kubecka, M., 'Prawa i Sprawiedliwa. Polityka Kulturalna PIS' (Right and Fair. Cultural Policy of Law and Justice), 2015, [Online] available at http://publica.pl/teksty/prawa-i-sprawiedliwa-polityka-kulturalna-pis-53554.html, accessed on June 15, 2019.

35. Litvack, J., Ahmad, J. and Bird, R., 'Rethinking Decentralization in Developing Countries', The World Bank, Washington, 1998, [Online] available at http://www1.worldbank.org/pub licsector/decentralization/Rethinking\%20Decentralization.pdf, accessed on June 14, 2019.

36. Loewen, B., 'From Decentralization to Re-centralization: Tendencies of Regional Policy and Inequalities in Central and Eastern Europe', 2018, Administrative Culture, vol. 18, no. 2, pp. 103-126.

37. Manor, J., 'Perspectives on Decentralization', Swedish International Centre for Local Democracy, Working Paper no. 3, 2011, [Online] available at https://icld.se/app/uploads/files/ forskningspublikationer/icld-wp3-printerfriendly.pdf, accessed on June 14, 2019.

38. Ministry of Culture and National Heritage, 'Rejestry fundacji i instytucji kultury' (Registers of Cultural Foundations and Institutions), [Online] available at http://bip.mkidn.gov. $\mathrm{pl} /$ pages/rejestry-ewidencjearchiwa-wykazy/rejestry-fundacji-i-instytucji-kultury.php, accessed on June 15, 2019.

39. Ministry of Culture and National Heritage, 'Sprawozdanie z Wykonania Budżetu Państwa i Budżetu Środków Europejskich w Części 24 i Dziale 921 - Kultura i Ochrona Dziedzictwa Narodowego za Lata 2016, 2015, 2014, 2007' (Report on the National Public Budget Execution and EU Budget Execution in the 24 Part and 921 Unit - Culture and National Heritage Protection in 2014, 2015, 2016, 2007), [Online] available at https://www.gov.pl/web/kultu ra/budzet-ministerstwa, accessed on June 16, 2020.

40. Murzyn-Kupisz, M., 'Cultural Policy at the Regional Level: A Decade of Experiences of New Regions in Poland', 2010, Cultural Trends, vol. 19, no. 1-2, pp. 65-80.

41. Musiałek, P., Ociepka, T. and Kędzierski M., 'Dostateczna Zmiana. Ranking Polityk Publicznych 2015-2019’ (Sufficient Change. Ranking of Public Policies 2015-2019), Klub Jagielloński, 2019, [Online] available at https://klubjagiellonski.pl/wp-content/uploads/ 2019/10/dostateczna-zmiana-ranking-polityk-publicznych-2015-2019.pdf, accessed on June 14, 2019. 
42. Najwyższa Izba Kontroli (Supreme Audit Office), 'Informacja o Wynikach Kontroli Wykonania Budżetu Państwa w 2017 w Części 24 - Kultura i Ochrona Dziedzictwa Narodowego Oraz Wykonania Planu Finansowego Funduszu Promocji Kultury' (Information on the Results of the Control of the Implementation of the State Budget in 2017 in Part 24 - Culture and National Heritage Protection and Implementation of the Financial Plan of the Culture Promotion Fund), 2018, [Online] available at https://www.nik.gov.pl/plik/id,17042.pdf, accessed on June 15, 2019.

43. 'Oświadczenie Dariusza Stoli. Niechciany Przez PIS Dyrektor Gotów Odejść 2020' (Dariusz Stola's Statement. The Director Unwanted by the Law and Justice Ready to Leave), February 11, 2020, [Online] available at https://www.onet.pl/kultura/onetkultura/oswiadcze nie-dariusza-stoli-niechciany-przez-pis-dyrektor-gotow-odejsc/b53htv6,681c1dfa, accessed on February 25, 2020.

44. Panday, P., 'Decentralization without Decentralization: Bangladesh's Failed Attempt to Transfer Power from the Central Government to Local Governments', 2017, Asia Pacific Journal of Public Administration, vol. 39, no. 3, pp. 177-188.

45. Paquette, J. and Redaelli, E., Arts Management and Cultural Policy Research, New York: Palgrave Macmillan, 2015.

46. Paszulka, W., “Dzisiaj to Karykatura Misji Edukacyjnej’. Dwa Lata Muzeum II Wojny Światowej' ('Today Is a Caricature of an Educational Mission'. Two Years of the Second World War Museum'), March 23, 2019, [Online] available at https://www.tokfm.pl/Tok $\mathrm{fm} / 7,103085,24552638$,dzisiaj-to-karykatura-misji-edukacyjnej-dwa-lata-muzeum-ii.html, accessed on February 25, 2020.

47. Pina-Sánchez, J., 'Decentralization as a Multifaceted Concept: A More Encompassing Index Using Bayesian Statistics', 2014, Revisita Española de Ciencia Política, no. 34, pp. 9-34.

48. Pollit, C., 'Decentralization. A Central Concept in Contemporary Public Management', in Ferlie, E., Lynn, L.E. and Pollit, C. (eds.), The Oxford Handbook of Public Management, Oxford: Oxford University Press, 2005, pp. 371-397.

49. Pritchett, L., Woolcock, M. and Andrews, M., 'Capability Traps? The Mechanism of Persistent Implementation Failure', Center for Global Development, Working Paper no. 234, 2010, [Online] available at https://www.cgdev.org/sites/default/files/1424651_file_Pritch ett_Capability_FINAL.pdf, accessed on June 15, 2019.

50. 'Program wyborczy PiS. Zdrowie, Praca, Rodzina' ('Health, Labor, Family'), Warszawa, 2014, [Online] available at http://pis.org.pl/dokumenty?page=2, accessed on June, 16, 2020.

51. 'Program wyborczy PO. Następny krok. Razem' ('The Next Step. Together'), Warszawa, 2011, [Online] available at https://wyborcza.pl/1,75398,10264832,Program_wyborczy_ PO___Nastepny_krok_Razem___PDF_html, accessed on June 16, 2020.

52. 'Program wyborczy PO. Polska zasługuje na cud gospodarczy' ('Poland Deserves the Economic Miracle'), Warszawa, 2007, [Online] available at http://docplayer.pl/493629-Pro gram-wyborczy-platformy-obywatelskiej.html, accessed on June 16, 2020.

53. Prud'homme, R., 'The Dangers of Decentralization', 1995, World Bank Research Observer, vol. 10, no. 2, pp. 201-220.

54. Rodríguez-Pose, A. and Ezcurra, R., 'Does Decentralization Matter for Regional Disparities? A Cross-Country Analysis', 2010, Journal of Economic Geography, vol. 10, no. 5, pp. 619-644. 
55. Rose-Ackerman, S., 'Governance and Corruption', in Lomborg, B. (ed.), Global Crises, Global Solutions, Cambridge: Cambridge University Press, 2004, pp. 301-362.

56. Sahin K.E, Smoothing Centralization - Decentralization Cycles, Cambridge: Massachusetts Institute of Technology, 1973.

57. Shah, A. and Shah, S., 'The New Vision of Local Governance and the Evolving Roles of Local Governments', in Shah, A. (ed.), Local Governance in Developing Countries, Washington, D.C.: World Bank, 2006, pp. 1-46.

58. Sharma, C.K., 'Decentralization Dilemma: Measuring the Degree and Evaluating the Outcomes', 2006, Indian Journal of Political Science, vol. 67, no. 1, pp. 49-64.

59. Sharma, C.K., 'Why Decentralization? The Puzzle of Causation', 2005, Synthesis, vol. 3, no. 1, pp. 1-17.

60. Suteu, C., 'Culture and the Structural Funds in Romania, European Expert Network on Culture', September 2012, [Online] available at https://www.interarts.net/descargas/inter arts2566.pdf, accessed on November 20, 2019.

61. Tóth, A., 'The Quality of Governance and Its Effect on Decentralization in the Cultural Sector of the European Union Member States', paper presented at ACEI Conference, Montreal, Canada, June 24-27, 2014, [Online] available at https://editorialexpress.com/cgi-bin/confer ence/download.cgi?db_name=ACEI2014\&paper_id=54, accessed on June 14, 2019.

62. Tóth, A., 'The Transformation of the Hungarian Cultural Policy: A 20-year Perspective', 2011, Society and Economy, vol. 33, no. 3, pp. 555-573.

63. Treisman, D., 'Decentralization and the Quality of Government', 2000, [Online] available at https://www.imf.org/external/pubs/ft/seminar/2000/fiscal/treisman.pdf, accessed on June 14, 2019.

64. Ustawa z dnia 9 listopada 2017 r. o zmianie ustawy budżetowej na rok 2017, Dz. U. z 2017, poz. 2162 (Act on the Change of the Budget Act of 9 November 2017, Journal of Laws from 2017, item 2162).

65. Verheijen, T., Smirl, L. and Kozáková, A., 'Rebuilding State Structures: Methods and Approaches. The Trials and Tribulations of Post-Communist Countries', UNDP/RBEC Policy Advocacy Papers, 2001.

66. Vestlund, N.M., 'Between Centralization and Decentralization. Decision Behavior in the EU's Multilevel Administrative System', ARENA Report no. 4/15, Centre for European Studies, University of Oslo, 2015, [Online] available at https://www.sv.uio.no/arena/en glish/research/publications/arena-reports/2015/arena-report-4-15(1).pdf, accessed on June 16, 2019.

67. Weeda, H., Suteu, C. and Smithuijsen, C. (eds.), The Arts, Politics, and Change: Participative Cultural Policy Making in South-East Europe, Amsterdam: Boekman Foundation, 2005.

68. White, S., 'Government Decentralization in the $21^{\text {st }}$ Century. A Literature Review', Center for Strategic and International Studies, December 2011, [Online] available at https://csiswebsite-prod.s3.amazonaws.com/s3fs-public/legacy_files/files/publication/120329_White_ Decentralization_Web.pdf, accessed on June 15. 2019.

69. Wyszomirski, M.J., 'Arts and Culture', in Salamon, L.M. (ed.), The State of Nonprofit in America, Washington, D.C.: Brookings University Press, 2002, pp. 187-218.

70. Yosifova, D., 'Towards Decentralized Cultural Policy in Transition Countries. The Case of Bulgaria', Master Thesis, Central European University, Budapest 2011. 